Összeállította: Ralovich Béla, ny. szakfötanácsos Eü. Min.

Reported by Béla Ralovich, past senior advisor, Ministry of Health

E-mail: ralovich.bela@freemail.hu

DOI: https://doi.org/10.29179/EgTud.2020.4.142-166

\title{
Adatok a gyógyítás hazai történetéhez
}

\section{Data to the history of the Hungarian curing}

\section{Összefoglalás}

A Magyar Királyságot a jelenlegi helyén 1000-ben ismerte el Szt. Ottó római császár és II. Szilveszter pápa. Ezt megelőzően és ezután is bencés papok gyógyítottak hazánkban. Kezdetben mellettük csak kisszámú külföldi orvos és peregrináció során tanult magyar „physicus” tevékenykedett. A papok itthoni képzése 1000 körül indult el a különböző iskoláinkban. Először Óbudán képeztünk orvost 1395-ben és később Pozsonyban, de mindkét helyen csak rövid ideig. Állandó orvosképzés csak 1770 óta van Magyarországon és jelenleg négy egyetemen is folyik.

Kulcsszavak: gyógyítás, papok, felsőoktatás, orvosképzés

\section{Abstract}

The Hungarian Kingdom was officially accepted by the Holy Roman Emperor Otto and by Pope Sylvester II. in 1000. Before and after that time Benedictine 
monks cured in our country. At the beginning besides them only a small number of foreign medical doctors and peregrinant Hungarian „physicus” worked. Education of priests started in our different schools around 1000. Medical training began first at Óbuda in 1395 and later in Pozsony but at both universities only for a short time. Permanent medical training has been going on in our country since 1770, at present even in four universities.

Keywords: curing, priests, higher education, medical training

\section{Elözmények}

Áttekintve a gyógyítás történetét, megállapítható, hogy az mindig szoros kapcsolatban állt a miszticizmussal/a vallásokkal, a filozófiával és az oktatás alakulásával. A kezdetektől évezredeken keresztül, az volt a gyakorlat, hogy a panaszos elment vagy elvitték őt a varázslóhoz, ill. a varázsló ment oda ahova hívták és aki a családján belül szerzett tudásának megfelelően, az általa ismert és gyűjtött növényi, állati és ásványi anyagokkal/a mai gyógyszerekkel, valamint késsel, varázslatokkal és imákkal kezelte a beteget. Ezután Egyiptomot említjük, ahol Kr.e. mintegy 4000 évvel alakították ki a szervezett oktatást a hieroglifikus írás tanítása céljából. Úgy tartják, hogy Thot volt az írás, a bölcsesség, a tudományok, a mágia istene, az írnokok pártfogója és az orvosok patrónusa. Kr.e. 2600 körül élt Imhotep, akit az első ismert orvosnak, építésznek, gyógyszerésznek, csillagásznak és írnoknak tartanak. Tevékenységének köszönhetően már „tudományos alapon” gyógyítottak a papok. Az orvosi ismeretek egyik korai forrása az un. Ebert-papirusz volt, mely Kr.e. 1550 körül készült és felölelte az akkori összes orvosi ismeretet - emberi test, betegségek, gyógyszerek, rovarirtó-szerek, stb. Úgy tartják, hogy abban találhatók Thot receptjei is. Egyiptomban már szakosodott orvosok is dolgoztak és szülőotthonok is léteztek. Az Ó-perzsa Birodalomban is voltak iskolák, ahol háromféle ékírást is hasz- 
náltak. Később a perzsák az orvostudomány területén is jeleskedtek. Kr.u. 529ben az Athénból elmenekült görög tudósok és orvosok a Gondesapurban létezett (fő)iskolán dolgoztak tovább. A városban kórház is volt. Az epidauruszok Kr.e. 2000 évvel Aszklepioszt - akinek orvos utódai, két fiú és Hügieia voltak - tekintik a gyógyítás és a gyógyhatású szerek Istenének. A görög város-államok Kr.e. 800 és 600 között kezdtek kialakulni, melyek között a két legjelentősebb Athén és Spárta volt. Athénban Kr.e. 338-ban hozták létre az "Ephébiat", melyben magas szinten oktattak retorikát, valamint filozófiát. Ebben az időszakban élt Hippokratész (460-350 körül) is, aki a korai orvostudomány egyik nagy alakja. Ő gyüjtötte össze az egyiptomi ismereteket és maga is gyarapította azokat. Töle származtatják a még ma is alkalmazott „Orvosi eskü" szövegét, amiből kiderül, hogy az orvoslás még akkor is föleg "családi mesterség" volt és az oktatás ennek megfelelően a családon belül folyt. Írásából az is megállapítható, hogy a physicusok nem foglalkoztak a sebészettel, mely a chirurgusok szakterülete volt és, hogy a gyógyszereket az orvosok adták a tünetek alapján a betegeiknek. Platón (427-347) Kr.e. 387-ben Athénban alapította az „Akadémiát/ Museiont", az első olyan görög filozófiai iskolát, melyben már tanítottak matematikát, asztronómiát, zoológiát, botanikát és filozófiát - az utóbbi tudományok már kapcsolatosak voltak a gyógyítással. Szókratész (469-399) természet-filozófiája nagy hatással volt Platón gondolkodására, akinek a múvei az alábbi témák szerint csoportosíthatók: formatan, ismeretelmélet (dialektika), antropológia (etika), államelméletek, stb. Az Akadémiáját Justinianus bizánci császár csukatta be Kr.u. 529ben. Egyesek úgy tartják, hogy Platón Akadémiája tekinthető a későbbi „egyetemek" egyik elődjének, ahol Arisztotelész (384-322) is oktatott. Ő Platón tanítványa és Nagy Sándor nevelője, nagy formátumú filozófus és irodalmár volt. Platónnal együtt mindketten évszázadokon keresztül az európai filozófia legmeghatározóbb alakjai voltak. 335 körül létrehozta saját iskoláját a "Lykeiont/a Peripatost", melyben már jelentősebb könyvtár is volt. Kr.e. 290 körül az Athé- 
ből elmenekült tudósok alapították meg az Alexandriai Iskolát/a Museiont az uralkodók támogatásával. Itt alakították ki a kor legnagyobb papirusz-tekercs könyvtárát a világszerte fellelhető tudományos múvekből, melyek két heIyen - a Museionban és a Serapis templomában - voltak olvashatók. A kutatók matematikával, csillagászattal, orvosi és filozófiai ismeretekkel foglalkozhattak, ill. ilyen ismereteket tanulhattak/tanítottak. Talán ez volt az első jelentős, nyilvános orvosi iskola. 610-től kórház is müködött a városban. Kr.e. 146-ban a Római Birodalom bekebelezte Görögországot és ekkor a görög tudomány, kultúra, építészet és müvészet is a Birodalom részévé vált. Az időszámításunk kezdetén élt Krisztus (0-33?), aki megteremtette a szeretetre és a segítségnyújtásra épülő keresztény filozófiát. A követői az apostolok, a szerzetesek - a továbbiakban ennek megfelelően tevékenykedtek. Rómában az első akadémiát a Kr.u. első században Vespasianus császár ((9-79)) hozta létre. Ebben az időszakban alapították meg azt a Jogi iskolát is, ahol az ún. „római jogot” oktatták. A Pergamonban született Aelius Gale-
nus/Claudius Galenus (129-210?) physicus, chirurgus és filozófus volt, aki Rómában élt és dolgozott. Ő tekinthető az egyik legjelentősebb ókori orvos-kutatónak. Munkássága kiterjedt az anatómiára - majmokat és sertéseket boncolt -, a fiziológiára - a humorális elméletet fejlesztette, a keringési rendszert és az idegmúködést kutatta -, a kórbonctanra, a gyógyszertanra és a neurológiára. Ezek mellett foglalkozott filozófiával és logikával is. Nézetei mintegy 1300 évig meghatározták az európai orvosok gondolkodását. Az Alexandriai könyvtár anyaga a Kr.u. 200-as évek második felében részben megsemmisült, részben széthordásra került. Az afrikai származású Martianus Minneus Felix Capella (360-428) író volt. Ő írt először „A hét szabad müvészet/Septem artes liberales" rendszerről allegorikus formában, kilenc kötetben. Könyve címe „De nuptiis Philologiae cum Mercurii et de septem artibus liberalibus libri IX"/"Kilenc könyv Mercurius és Philologia házasságáról és a hét szabad múvészetről". A tudományok rendszerét Mercurius és Philologia házasságának kerettörténetébe ágyazta. Az első két könyvben ol- 
vasható, hogy Philologia nászajándékba kapja Mercurius hét szolgálóleányát. A maradék hét kötetben kötetenként egy-egy tudományt ismertetett. Ezek a következők voltak: grammatika, retorika, logika (trivium). A logika Arisztotelész és Porphüriosz munkájából állt. Ezután következtek a quadrivium tárgyai: aritmetika, geometria, asztronómia, zene. Voltak választható tárgyak is. Ilyen volt Arisztotelész Fizikája. Ez a rendszer képezte az oktatás alapját Európában évszázadokon keresztül. Az emberiség jövője szempontjából nagy jelentőségú volt, hogy I. Nagy Constantinus ((306-337)) elismerte a keresztény vallást, Konstantinápolyba költözött és ott főiskolát is alapított, melynek több tanszéke is volt. Bizáncban az oktatás már akkor „egyházira” és „államira” küIönült. A Római Birodalom 395-ben kettészakadt. Területén jelentős kolostorok múködtek kiemelkedő képességú szerzeteseknek köszönhetően. Ők többek között fontos, föleg teológiai és filozófiai kutató és oktató munkát végeztek. Ezek voltak: Nagy Szt. Vazul (329-379; Caesarea), Szt. Ágoston (354-430; Hippo), Szt. Benedek (480-543; Monte Cassino), Szt.
Isidor (556-636; Sevilla), stb. Mivel ők papok voltak, tanaik elismerése a mindenkori pápától függött. Nézeteiket az írásaik és a követőik terjesztették. Nagy Szt. Vazul 369-ben megalkotta a kolostori élet követendő példáját a basileiost, amely kórház, az elesettek számára szállás, stb., volt. 420-ban Jeruzsálemben is müködött kórház. II. Theodosius (401-450) keletrómai császár három jelentős tettet hajtott végre. 425-ben megalapította a korábbi főiskolából a Pandidakteriont, ahol görög és latin nyelvet, szónoklattant, jogot és filozófiát oktattak. Ez a Főiskola a Bizánci Birodalom legfontosabb kulturális központjává vált. 431-ben Efezusban egyetemes egyházi zsinatot tartott, ahol a nesztoriánus nézeteket elítélték és Szt. Cirill nézetét fogadták el. Végül elrendelte a hivatalos császári rendeletgyüjtemény, a Codex Theodosianus elkészítését. Meg kell még azt is említenünk, hogy egyesek szerint az „első egyetem” az ún. Magnaura Iskola volt, melyet 855/56ban a Pandidakterionból alakítottak ki és ahol filozófiát, retorikát, orvosi ismereteket és jogot oktattak 1046-ig. Akkor újraalapították a jogot és filozófiát taní- 
tó Pandidakteriont, mely a Birodalom 1453 évi megszűnéséig működött, Platón tanait a legtovább oktatva. A bizánciak szerepe azért is jelentős, mert hasonlóan az arabokhoz, ők is szerepet játszottak a klasszikus müvek megőrzésében. Szt. Benedek később Szt. Vazul nézetei alapján dolgozta ki a bencések életének és kolostoraik müködésének a szabályait. A kolostoraik egy része rendelkezett kórházzal, érvágó- és orvosok-házával, könyvtárral, fürdővel, gyógyszertárral és gyógynövénykerttel is. Az ott élők imádkoztak, istentiszteleteket tartottak, oktattak, a tudományokkal foglalkoztak - fordítottak és másoltak a scriptoriumban -, gyógyítottak - az orvosi munka akkor három tudományra (életmód/dietetica, orvosságok/pharmaceutica és késsel végzett beavatkozások/chirurgia) épült -, termesztettek gyógynövényeket, mezőgazdasági munkát végeztek és állatokat tartottak. Az oktatás színvonalának későbbi alakulására - az orvosi ismereteket is beleértve - nagy hatással volt a római M. Aurelius Cassiodorus (490585) történész, államférfi, pap munkássága, mert ő összegyűjtötte és másol- tatta az antik tudományos múveket a kolostorában a „barbár” évszázadok elején. Ezzel megmentette a fontos dokumentumokat az utókor számára. A hét szabad művészet koncepciójának a VII. századi elterjedésében a Karolingok uralkodásának volt jelentős szerepe. Ők hívták meg az angol teológust Alcuin-t/ Albinus-t (735-804), hogy tanítson az udvarukban, aki iskolát és könyvtárat is alapított. Az oktatás mellett Nagy Károly tanácsadója volt, aki jutalmul neki adta a toursi Szent Márton Apátságot, ahol Európa egyik legjobb iskoláját alakította ki. Utóda az ír John Scotus Erigena/Johannes Scotus Eriugena (810877) teológus, fordító, értelmező volt, aki több korábbi szerző munkája alapján megpróbálta integrálni a klasszikus görög és a neoplatonista filozófiát a keresztény hittel. Egyesek szerint munkássága később Hegel-re is hatással volt. A szerzetesek közül az orvostudomány területén a legjelentősebb személy Constantinus Africanus (10201087) bencés barát volt, aki dolgozott a salernoi Orvosi Iskolában és Monte Cassinoban élt. Ő fordította latinra a korábban élt görög és arab orvosok meg- 
mentett múveit, használhatóvá téve azokat az utókor szakemberei számára.

Az iszlám aranykora a Kr.u. a 700as évektől az 1400-as évekig tartott. Az általuk uralt területeken a gazdasági, a tudományos, a társadalmi és a kulturális élet az akkori legmagasabb szinten állt. Ami a pápáktól független arab oktatást illeti, az iskoláik mindig a jelentős mecsetek szomszédságában épültek. Bagdadban hozták létre az első „Fordító Irodát" 830-ban. Az arab iskolákat az alábbi sorrendben alapították: a tuniszi (Al-Zaytuna Iskola, 732), a cordobai (Mezquita, 785), a fezi (Al-Zaytuna Iskola, 859), a kairói (Al-Azhar Iskola, 970), a bagdadi (Al-Nizamiyya Iskola, 1065), stb. Ezekben a világ addigi eredményeit gyüjtötték össze, fordították le és oktatták. Papjaik munkáját megkönnyítette, hogy 751-ben megismerték a papír készítés technikáját. Iskoláikban, ahol jelentős könyvtárak létesültek, színvonalas orvosképzés is folyt. A hallgatók a végzéskor diplomát kaptak. Az arab orvosoknak általában és különösen a perzsa orvos, költő, filozófus és teológus Ibn Szína-nak/Avicenná-nak (980-
1037) köszönhetően, az orvosi ismeretek jelentősen gyarapodtak. Avicennát tartják a modern európai orvoslás egyik megalapozójának. Az arab területeken is múködtek kórházak: Damaszkuszban (707), Kairóban (874), Bagdadban (918), Baszrában (925), stb., ahol oktatás is folyt. Az első gyógyszertárat Bagdadban nyitották meg 754-ben. Attól kezdve az arabok által uralt területeken már máshol is létesültek gyógyszertárak.

Az orvostudomány európai oktatása és múvelése területén nagy előrelépés történt az arabok hatására a IX. században. Akkor hozták létre az itáliai Salernoban a pápai befolyástól mentes Orvosi Iskolát, mely a XIII. század végéig fontos tudományos központ volt. Ezt követte az 1180-ban megalapított montpellieri Orvosi Iskola. Az oktatás területén pedig jelentős haladást eredményezett Hugo de Saint-Victor (10961141) munkássága. Ő 1120 tájától a párizsi Szt. Vince Apátságban dolgozott. Hatalmas gondolkozó, skolasztikus teológus, misztikus író, Ágostonrendi kanonok volt, akinek a tevékenységére jelentős hatást gyakorolt Szt. Ágoston filozófiá- 
ja. Ő írta a "Didascalion"/"De eruditione didascalica" c. enciklopédiát, melyben az akkor ismert összes tudományt öszszefoglalta. Ezek között találhatók az ún. "Septem artes mechanicae-be" azaz A hét mechanikai müvészet-be tartozók is. Ezek a takácsmesterség, kovácsmesterség, épitőmúvészet, hajózás, földmüvelés, vadászat, színjátszás és gyógyítás. Ezek a tudományok a physica témakörébe tartoztak és a physicus/ orvos elnevezés is innen eredeztethető.

Európában a XIII. században születtek meg az első egyetemek a már régóta müködő kolostori iskolákból párizsi, bolognai, montpellieri, stb. - melyeken már nemcsak egy-egy témakört (jog vagy teológia), hanem a hét mechanikai múvészet tárgyait is elkezdték oktatni. Ezeket a tárgyakat az egyetem előkészítő fakultásán, a facultas artiumon, a mai bölcsészeti kar ősén adták elő, melynek elsajátítói a „magister artium liberalium"/,sszabad müvészetek tanítómestere" címhez jutottak. A Salernoban végzettek 1231 után orvosi diplomát kaptak. Ez alapján is írta elő II. Frederick azt, hogy csak diplomával rendelkező személyek gyógyíthatnak 1240-től. A véres sebészeti beavatkozások végzésétől a papokat már 877-től tiltották. Az orvosi diplomával nem rendelkező papok gyógyításban játszott szerepe ezek után már csökkent. A fejlődés következő stációját az jelentette, amikor az orvosi és a gyógyszerészi feladatokat elválasztották egymástól. Az arabok által megszállt területeken ez folyamat már 1162-ben elkezdődött, míg máshol csak az 1240-es dekrétum után indult el.

\section{Az orvosi ismeretek oktatása hazánkban}

A természetimádó őseinknek a sámán volt a misztikus vezetője. Elődjeink az egy Istent tisztelő keresztény, mohamedán és zsidó vallással és azok szerzeteseivel/papjaival valószínü, hogy a kazárokkal való együttélés során Kr.u. 500-600-as években találkoztak, de az is lehet, hogy esetleg már korábban - a perzsa és a szkíta időszakban. Őseink életére a megismert vallások közül a bizánci szerzeteseknek, a bizánci 
kereszténységnek, valamint a bizánci császároknak volt a legnagyobb hatása a honfoglalás előtt és utána is egy darabig, mert bizánci papok már voltak közöttünk, akik kereszteltek is és a mindenkori császárral is együttmúködtünk. Ennek ellenére őseink zömében még az ősi pogány vallásuk szerint éltek.

$A z$ is bizonyos, hogy a Kárpát-medencében, már a honfoglalás előtt is voltak római katolikus templomok, katakombák, bizánci és bencés kolostorok, valamint szerzetesek és esetleg szerzetesnők is. Ugyanis a kereszténység már Kr.u. a II. században, a római uralom alatt, megjelent Pannoniában. E területen a rómaiakon kívül (Kr.u. 10430 között), germán törzsek (?), gótok (az 5. században), hunok (448-tól), longobárdok (520-tól), avarok (560-től) és szlávok (800-as évektől) is éltek. Közülük a rómaiak, a gótok, a longobárdok, az avarok és a szlávok között már tevékenykedtek keresztény szerzetesek. 850 körül a keresztény Pribina ((?-860?)) /a kettős zárójelben lévő évszámok az illető uralkodásának kezdő és záró évét jelölik/ nemcsak a mai Zalavár helyén létesített erődítményt és templomot, hanem a nyitrazobori hegyen is alapított kegyhelyet. Ezeken a helyeken valószínúleg salzburgi bencések munkálkodtak. Pribina után Szvatopluk ((840-894)) következett. Ő támogatta a Rómából visszatért Metód térítő munkáját és az is bizonyított, hogy Cirill és Metód is élt Zalavár környékén. Tehát abban az időben bizánci és bencés kolostorok egymás mellett léteztek a Kárpát-medencében és valószínü, hogy az akkori gyakorlatnak megfelelően a szerzetesek már oktattak is.

Úgy tünik, hogy hivatalosan a nyugati kereszténységgel Kr.u. 961-ben Taksony ((947-970)) fejedelemnek köszönhetően kerültünk kapcsolatba. Taksony második kezdeményezésére 973 után már közöttünk is biztosan megjelentek a bencések. 982-ben Géza fejedelem ((970-997)) kérésére a Sankt Gallen-i Querfurti Brunot küldték ide, aki mint első püspök Gézát és még számos vezető személyt megkeresztelt és ezzel hivatalosan is letette a római katolicizmus alapját. Géza az új vallás elfogadását vas-szigorral megkövetelte. 
Jelen ismereteink szerint bencések létesítették az első magyar templomot, a veszprémi Szent György kápolnát és ők alapították meg az első kolostorukat, a pannonhalmit is 996-ban. A római katolikus keresztény vallás és velük a nyugati kultúra azonban csak lassan, Géza utódja, Szent István király ((997-1038)) uralma alatt kezdett terjedni és a folyamat valószínúleg csak Nagy Lajos király ((1342-1382)) uralkodása alatt fejeződött be.

Az bizonyos, hogy hazánkban is szerzetesek oktattak először és egyházi személyek képzése volt a céljuk. Az is tény, hogy Szent István királyunk érdemei a hazai oktatási rendszer megszervezése területén elévülhetetlenek. Az oktatás három szinten: a. kolostorokban, b. templomokban/plébániákon és c. székesegyházi/káptalani iskolákban indult el. Szt. István támogatta a szerzetesi kolostorok létesítését (Pécsvárad (998), Zalavár, Zoborhegy, Csanád, Bakonybél). Ezt a tevékenységet az őt követő többi királyunk is folytatta (Tihany, Garamszentbenedek, Mogyoród, Somogyvár, Szekszárd, Báta, Kolos,
Meszes, Földvár, stb.). Ezek a létesítmények voltak az ún. királyi apátságok. A kolostorokban vagy monostorokban éltek a bencések, akik istentiszteleteket tartottak, térítettek, oktattak, gyógyítottak, gyógynövényeket termeltek és vándorokat is fogadtak. A kolostori iskolákban az elemi ismereteket - beszédet, kiejtést, hangsúlyozást, olvasást, írást, éneket és számvetést - tanítottak képzetlen személyeknek, fiataloknak általában három-négy évig. (Itthon létezik egy olyan dokumentum, amelyet egy esztergomi vagy székesfehérvári diák készített a XII. század első felében, és amely arról tanúskodik, hogy a hét szabad múvészetből többnyire csak a triviumot tanították. A quadrivium tárgyainak tanítása kezdetben ritka lehetett.) Pannonhalmán már 1010 körül volt iskola és itt oktatták először a quadriviumi tárgyakat. Akkor és még hosszú ideig a memorizálás, az ismétlés és a viszszakérdezés volt az oktatás módszere és a latin nyelv volt a hivatalosan használt állami, egyházi és oktatási nyelv. Később a leendő papok mellett a világi pályára készülők is ezekben az iskolákban tanultak. Az idők folyamán, a kolos- 
tori és/vagy a templomi/plébániai iskolákból alakultak ki a városi és az egyéb oktatási intézményeink. István másik rendelkezése a templom-építtetési volt, melynek eredményeképpen elindult az Isten-házához kapcsolódó népoktatás is 1020 táján. A vidéki templomokban folyt a legelemibb ismeretek - imák, szentírás, éneklés, számolás, valamint esetleg olvasás és írás - tanítása. Az "elemi népoktatás" általában magyarul folyt, de a latin nyelv tanítása is előfordulhatott. István harmadik nagy jelentőségü lépése a székesegyházi/káptalani iskolák, az academia capitularisok létesítésének támogatása volt. Ennek keretében jött létre ilyen iskola Székesfehérváron 1028 körül, Csanádon 1028 körül, Esztergomban 1030 táján és Pécsett még Szent István korában, majd Nyitrán 1717, Gyulafehérváron, Veszprémben, Nagyszombatban, Ó-Budán... stb." Ezekben az intézményekben már magasabb szintú oktatás folyt a triviumi és a quadriviumi követelményeknek megfelelően latin nyelven. Békefi Remig szerint 15 ilyen intézmény létezett hazánkban. A székesegyházi iskolák a főiskoláink elődjeinek tarthatók. A végzettek általában külföldön szerezték meg a magasabb egyetemi diplomát.

Hazánkban a bencések mellett 1130-tól új szerzetesek (premontrei, cisztercita, domonkos, ferences, Ágostonrendi, pálos, jezsuita, karmelita, piarista, irgalmas stb.) és 1527 után a protestáns tiszteletesek is megjelentek a bizánci szerzetesek mellett. Mindegyik rend létesített egy vagy több kolostort. A tatár-dúlás előtt a kolostorok száma már több mint 90 volt. A bencések után a többi oktató rend tagjai - a ciszterciták, a ferencesek, a domonkosok, az Ágostonrendiek, a jezsuiták stb. - is megszervezték iskoláikat. Az elmondottak alapján nyilvánvaló, hogy hazánkban évszázadokon keresztül szerzetesek/papok/tiszteletesek oktattak az Egyház és az adott szerzetes-rend előírásai/szabályai szerint, a kornak megfelelő módon.

Ami a hazai felsőfokú oktatás történetét illeti, e téren sok a vita. Elsősorban az esztergomi és a veszprémi Academia Capitularis, ill. a veszprémi, a budai és a pécsi Studium Generale tekintetében ütköznek a nézetek. A vita oka az, hogy 
szakembereink nézete eltérő. Szerintünk 1292 előtt egyetemről, a korábban elmondottak értelmében, nem is beszélhetünk. Addig csak skoláknak vagy akadémiáknak nevezték a szerzetesi iskolákat, ill. ha több tárgyat is oktattak, akkor az intézmény neve studium generale lehetett. Az bizonyosnak látszik, hogy a bölcsészet/a hét szabad múvészet elsajátítása nélkül nem lehetett teológiát, jogot vagy orvostudományt tanulni. Mindent összevetve mi úgy véljük, hogy kezdetben egy oktatási intézmény akkor lett studium generale vagy később egyetem/universitas, ha azt a pápa, a terület uralkodója kérése alapján, elismerte annak vagy hozzájárult annak létesítéséhez. Talán más volt a helyzet a nem bencés - pl.: domonkos - szerzetesi studium generalek esetében. Azok létesítését lehet, hogy csak a Rend, pápa által elismert, nemzetközi feje rendelte el és az intézményt az adott ország illetékese alapította meg. A protestáns iskolák megjelenése magával hozta a korábbi gyakorlat megváltozását, mert azok létesítésébe a pápáknak már nem volt beleszólása, azok uralkodói, fejedelmi vagy főúri enge- dély és támogatás alapján müködtek. Később az uralkodók pápától való függésének csökkenése azzal is járt, hogy egy-egy új létesítmény megalapítása esetén már nem kérték a pápa engedélyét. Hazánkban az említettek mindegyikére találni példát.

Mint korábban már elmondtuk Európában 1120 előtt a hét mechanikai múvészet tárgyait - közöttük az orvosi ismereteket is - nem vagy csak esetlegesen a hét szabad múvészet tárgyaiba ágyazott formában oktatták a kolostori iskolákban. Kivételek voltak egyes görög és római iskolák, az arab iskolák, a salernoi Orvosi Iskola és a montpellieri Orvosi Iskola - az utóbbi csak 1180 után. A fenti tényből következik, hogy 1120 előtt a székesegyházi iskoláink oktatási tematikája sem térhetett el ettől a gyakorlattól. Nemes Csaba és Farkaslaki Hints Elek szerint Esztergomban már oktattak orvosi ismereteket. Nemes szerint ezért az az Iskola egyetem volt. Békefi úgy vélte, hogy az orvosi ismeretek oktatása az esztergomi Székesegyházi Iskolában nem bizonyítható. Szerintünk a hét szabad múvészet tematikája min- 
dig tartalmazott orvosi ismereteket is, viszont ez még nem jelentette azt, hogy az adott intézmény egyetem. Másik fontos tény az, hogy az 1028-ban megalapított esztergomi Academia Capitularis még a bolognai Scola (1088) és a párizsi Iskola (1150) megszületése előtt létesült és mivel az utóbbiak csak a XIII. században lettek egyetemek, ezért az esztergomi Iskola elvileg sem tartható egyetemnek. Emellett jelenleg semmi olyan hivatalos dokumentumról sincs tudomásunk, amely a pápa jóváhagyását tartalmazza. Más a helyzet a veszprémi Academia Capitularis esetében. Szerintünk ez az intézmény, mely 1172 és 1196 között - valószínúleg 1180-ban - alakult ki egy (bizánci vagy bencés) szerzetesi iskolából, volt hazánk első Studium Generaleja, mely III. Béla király ((1172-1196, a horvát származású Kalán/ Calanus Coelius pécsi püspök megmérgezte)) támogatásával jött létre. Ennek az intézménynek a létét igazolja a IV. Kun László király ((1272-1290, megmérgezték)) által 1276. november 18án írt levél. Továbbá az is, hogy IV. Ince pápa ((1243-1254)) egy 1246-ban kelt oklevelében francia, magyar és olasz stu- dium generalekról írt. Jelen tudásunk szerint, abban az időben, csak Veszprémben létezett ilyen intézmény, melyben két tanszéken - bölcsészeti és jogi oktattak. Ezért ha ott orvosi ismereteket egyáltalán tanítottak, akkor az csak a hét szabad múvészet keretében történhetett meg. A veszprémi Studium Generale lerombolása után mintegy 25 év telt el addig, amíg a következő studium generálénk megszületett. A domonkosok alapították meg Budán a várban a Szent Miklós nevű konventjüket, melyben 1305?-ben szervezték meg az Aquinói Szent Tamás nevü Studium Generalet oktatási és térítési célból. A budai Intézményt maga a Rend tartotta fenn. A Studium Generalet állítólag 1475 után -1481?-ben - Mátyás király ((1458-1490)) támogatta. Az általa meghívott Franciscus Nardeus de Nerotino-t megbízta a Studium Generale egyetemmé fejlesztésével. Annyi bizonyos, hogy eredetileg a budai Intézményben bölcsészeti és teológiai képzés folyt és tudományos fokozatot is adtak. A Rend Capitulum Generaleja 1495-ben, majd 1507-ben is foglalkozott a budai Intézmény helyzetével, megerősítve jogait, 
és megállapította, hogy ők a bolognai Egyetem példáját követve oktattak. Hogy ez akkor ott mit jelentett, vagyis, hogy az Intézmény megnevezése mi volt - studium generale avagy egyetem - és, hogy hány kara volt, stb., azt nem ismerjük. Magyary-Kossa Gyula szerint 1483-ban a konstanzi zsinattal összefüggésben kétszer is említették a Budai Egyetemet/Főiskolát és annak tanárát Klostein Simont, aki orvos volt. Az 1510es években az Intézményt Párizsban tanult professzorokkal erősítették meg, melyben 1540-ig folyamatosan oktattak és neveltek. Akkor a domonkosok Kassára menekültek a törökök elöl, ahol később az Intézményük végleg megszúnt.

A pécsi Studium Generalet Nagy Lajos király ((1342-1382)) és Koppenbachi Vilmos/Vilmos püspök alapította - 1367-1543? -, és két tanszéke volt. A létesítés gondolatát indukálhatta az a tény is, hogy abban az időben alapították a prágai Egyetemet (1348), ill. a krakkói (1364) és a bécsi (1365) Studium Generalet. Pécs városa abban az időben hazánk egyik legjelentősebb települése volt. A studium generale alapítását
V. Orbán pápa ((1362-1370)) hagyta jóvá 1367 szeptemberében. Az alapító levelében az olvasható, hogy: „.... létesüljön egy Studium Generale, ahol örök időkre tanítsák az egyházjogot és a polgárjogot, valamint minden más tisztes tudományt, kivéve a teológiát...". Hogy a minden más tisztes tudomány pontosan mit jelent, azt nem ismerjük, de a kor gyakorlatát figyelembe véve az a bölcsészet, azaz a hét szabad múvészet oktatását jelenthette. Orvosi Tanszék Pécsett nem volt. Az Egyetem Nagy Lajos halála utáni sorsáról kevés biztosat tudunk.

Nagy Lajos után Zsigmond király ((1387-1437)) került a trónra és ő alapította az első hazai egyetemet/universitast az Universitas Budensist Óbudán - 1389-1403 -, melyet IX. Bonifác pápa ((1389-1404)) 1395. október 6-án ismert el. Abban az időben Óbuda egy fontos település volt különböző szintű iskolákkal, közöttük a domonkos Studium Generalejával és jelentős káptalan testülettel. Zsigmond király a káptalan testületre alapozva alakította ki az Egyetemet, melynek négy - bölcsészeti, 
teológiai, kánon és polgári jogi, valamint orvosi - tanszéke volt, és fokozatot is adhatott. Az alapításban, sok más mellett szerepe lehetett annak, hogy hazánkban orvosi tanszék korábban még nem volt. Azt sem tudni, hogy a pécsi Studium Generale, az 1387-ben történt báni megszállást követő leállás után elkezdett-e már ismét oktatni, továbbá, hogy nem változott-e a struktúrája. Emellett hazánk déli határvidékén abban az időszakban rendszeresek voltak a főúri, hatalmi lázongások. A óbudai Egyetem, a zavaros politikai és hatalmi viszonyok miatt 1403-ban bezárt. A körülmények normalizálódását követően Zsigmond király az Egyetem újraindítását kezdeményezte, ami 1410. augusztus elsején megtörtént a régi formában. Az Intézmény irányításában és a katolikus egyházvezetés újraszervezésében Castiglione Branda-nak, a volt piacenzai püspöknek és pápai követnek, aki később királyunk tanácsadója is lett, fontos szerepe volt. Mivel az az időszak a „kettős pápaság kora” volt, az Egyetemet, mely 1410-1447? között múködött, akkor az ellenpápa, XXIII. János ismerte el. Az újra megnyitott Egyetem kan- cellárja továbbra is a budai prépost volt. Orvosi ismereteket tanított Klostein Simon, Diernecki Máté és András mester is. Zsigmond királynak köszönhetően a budai és a bécsi Egyetem együttműködött. Az Egyetem Zsigmond király halála után több mint tíz évvel, ismeretlen okból megszűnt.

Zsigmond király Egyeteme után Mátyás király és Vitéz János érsek ((1465-1472)) hozták létre a rövid életű Universitas/Academia Istropolitanat Pozsonyban - 1465-1491. II. Pál pápa ((1464-1471)) volt a jóváhagyó az 1465. május 19-i bullájával. Mátyás király határozhatta meg az Egyetem helyét, a fakultásokat és választhatta ki az oktatókat is, valamint az ő és az érsek kötelessége volt az Egyetem müködési költségeinek a fedezése. Az Egyetemet Vitéz János és Janus Pannonius szervezte meg bolognai példa alapján, melynek első kancellárja Vitéz János volt a haláláig. Az Egyetemen bölcsészeti, teológiai, jogi, valamint orvosi tanszék müködött. Orvosi ismereteket Förchlinger Péter mester, Ilkusch Márton és Müller von Köningsberg Johannes/ 
Regiomontanus oktatott. Az Egyetem a Vitéz János-féle összeesküvés leleplezését követően hanyatlani kezdett és Mátyás halála után megszűnt. Az Egyetem mellett Mátyás király nemcsak a híres Könyvárát hozta létre, hanem a támogatásával 1473-ban Hess András hazánk első könyvnyomdáját is megalapította Budán. Az Egyetem megszűnése után, Pozsony városában 1912-ig, az Erzsébet Tudományegyetem megalapításáig, csak királyi, jogi és különböző felekezeti akadémiák/lyceumok müködtek.

A következő felsőoktatási intézményünket, a kolozsmonostori Jezsuita Iskolából alakították ki, melynek igazán viharos élete volt. Az iskolát Báthory Kristóf vajda 1579-ben alapította, melyet Báthory István fejedelem ((15711586)) kérésére XIII. Gergely pápa ((15721585)) 1582. február 9-én Egyetemnek ismert el. Az Egyetemet a protestánsok 1603-ban lerombolták. 1693-ban indult el ismét az oktatás az új jezsuita Akadémián, amelyet 1753-ban Mária Terézia királynő ((1740-1780)) megint Egyetemmé nyilvánított. Az Intézmény 1773 után, mint piarista Egyetem mü- ködött és 1775-től már Orvosi Tanszéke is volt. II. József király ((1765-1780)) 1784-ben Lyceummá minősítette és az Orvosi Tanszékből később Orvos-Sebészeti Tanintézet (1817-1872) lett és így oktatott addig, amíg 1872-ben Ferenc József király ((1848-1916)) egy új állami Tudományegyetemet nem szervezett Kolozsvárott. Ez az Egyetem még sok nehézséget megélve (a trianoni béke-diktátum miatt Szegedre menekült, majd visszatérés Kolozsvárra) ma is létezik, azonban 1959-től már csak, mint román tannyelvű Babes-Bolyai Tudományegyetem, melynek vannak magyar nyelvü tanszékei is. A kolozsvári Ferenc József Tudományegyetem Orvosi Kara 1945-ben, helyhiány miatt, Marosvásárhelyre szorult és ott kezdett el oktatni, mint Magyar Orvosi és Gyógyszerészi Intézet. Ennek az Intézménynek külön további kálváriája van. A neve jelenleg „George Emil Palade” Orvosi, Gyógyszerészeti, Tudomány és Technológiai Egyetem, melyben már román és magyar nyelven oktatnak.

A kolozsvári Egyetemet követte, a református Bethlen Gábor fejedelem 
((1613-1629)) és király ((1620-1621)) által 1622-ben Gyulafehérvárott alapított, nemzetközi hírű Collegium Academicum/Egyetem, melyet 1658-ban török/ tatár csapatok romboltak le. Az Egyetemen az indulásától kezdve, hosszabb vagy rövidebb ideig, neves külföldi és hazai szakemberek, közöttük Alstedt Johann Heinrich teológus, filozófus, polihisztor és Ascanius Mihály bölcsészés orvos-doctor, stb., oktattak. Azt nem tudjuk, hogy volt-e Orvosi Tanszéke és, hogy az orvosi ismeretek oktatása miIyen mélységü volt. A lerombolt gyulafehérvári Egyetem jogutódjaként müködött 1662 és 1896 között Nagyenyeden a híres, felsőfokon oktató, protestáns Kollégium, melyet Apafi Mihály fejedelem ((1661-1690)) hozott létre. A Kollégiumban jónevű szakemberek: Pápai Páriz Ferenc (filozófus, orvos, szótárkészítő), Enyedi Sámuel (orvos-doctor, bölcsész, prédikátor), Csernátoni Pál (számtan és filozófia tanár), Dézsi Márton (református esperes, hittudós) és később Baritz Márton (orvos-doctor), stb., oktattak. Hogy a hallgatók milyen orvosi ismereteket kaptak és a képzettségük mire jogosította őket, azt nem ismerjük, de az biztos, hogy legalább 1817-től Baritz barom-orvosi anyagot is tanított. Ennek a Kollégiumnak az élete sem volt zavartalan, mert 1704-ben az osztrák csapatok, majd 1707-ben a labancok pusztították el és csak I. György ((1714-1727)) brit király segítségével épült újjá.

Az első olyan - az induláskor ugyan csak kétkarú - Egyetemet, amely hazánkban a megalapításától kezdve még ma is folyamatosan müködik, Pázmány Péter esztergomi érsek ((1616-1637)), majd 1629-től élete végéig bíboros, szervezte meg 1635-ben Nagyszombatban. (Ennek az új jezsuita Intézménynek már volt előélete, mert az elődje, mint Káptalani Iskola már a XIII. századtól működött.) Az új Intézményt kezdetben csak II. Ferdinánd király ((1619-1637)) ismerte el. Az egyetemi képzés a Bölcsészeti és Filozófiai Tagozaton indult logika, physica, mathesis, metaphysica és ethica tanításával, de a Hittudományi Karon is elkezdték a casuisticat oktatni. Azonban ez a Tagozat csak 1638-ban vált teljessé, mert csak akkor jelentek meg az első olyan hallgatók, akik a hároméves bölcsészeti kurzust már teljesítették. 
Az Egyetem Jogi Kara Lósi Imre érsek ((1637-1642)) és utóda Lippay György érsek ((1642-1666)) adományainak köszönhetően alakult meg, és 1667-ben fogadott először hallgatókat. Lósi Imre és Lippay György főpapok az életük során több más jelentős tudomány-politikai tettet is végrehajtottak. Az Egyetemnek volt komoly könyvtára, csillagvizsgálója és nyomdája is. A negyedik Kart, az orvostudományit Mária Terézia 1769-ben alapította és az oktatás 1770-ben indult. A Karon physicusokat, chirurgus- és gyógyszerész-mestereket, valamint bábákat kezdtek képezni. A nagyszombati Egyetemet 1777-ben Budára költöztették és ott újból felavatták, majd 1784ben tovább vitték Pestre, mely helynek ma Budapest a neve. 1945 után a Pázmány Péter Tudományegyetem neve és struktúrája is megváltozott. Az Orvosi Kar 1951-ben kivált belőle és önálló egyetem lett, amely ma Semmelweis Ignác nevét viseli. 2017. augusztus 1-tôl az Egyetemet az Általános Orvostudományi, a Fogorvos-tudományi, a Gyógyszerész-tudományi, az Egészségtudományi és az Egészségügyi Közszolgálati, valamint az ún. Pető András Kar alkotja, melyeken hazai és külföldi hallgatók képzése és továbbképzése folyik.

Még a Budán lévő Egyetem Orvosi Karán indult el az állatjárványtani ismeretek oktatása (1783), és ebből a magból fejlődött ki a későbbi, az 1851-től önálló állatorvos-képzésünk.

A következőkben a XX. században alapított és az orvosaink képzésében, valamint továbbképzésében szerepet játszó fő intézményeinket fogjuk felsorolni.

- Ferenc József király 1912-ben alapította a Magyar Királyi Erzsébet Tudományegyetemet Pozsonyban. Az Orvosi Karon az oktatás 1918-ban indult. 1919-ben a csehszlovák invázió után az Egyetem oktatói Budapestre menekültek, majd az Egyetem 1923-tól négy karral - jogi, orvostudományi, bölcsészeti és evangélikus lelkészi - Pécsett kezdett működni. 1951-ben az Orvosi Kar önálló Orvostudományi Egyetem lett. Az Orvosi Karon 1973/74-ben elkezdődött a fogorvosképzés, mely jelen- 
leg a Fogorvosi Szakon folyik. 1990től létrejött az Egészségtudományi Főiskola. 2000-ben kialakult a Pécsi Tudományegyetem (PTE) a Janus Pannonius Tudományegyetem, a Pécsi Orvostudományi Egyetem és a szekszárdi Illyés Gyula Tanárképző Főiskola egybeolvadásával és attól kezdve az orvosképzés a PTE Általános Orvostudományi Karán folyik. Ekkor indult el a gyógyszerészképzés is. Az Egészségtudományi Főiskola 2006-ban egyetemi kar lett. A Gyógyszerész Szak 2016. január 1-től Gyógyszerész-tudományi Karként müködik.

- A Debreceni Egyetem alapítását ugyancsak 1912-ben határozták el. Az oktatás 1914-ben indult a Református Hittudományi, a Jog- és Államtudományi és a Bölcsészet, Nyelv és Történelemtudományi Karokon. Az új Egyetemet hivatalosan 1918-ban nyitották meg. Többéves építkezés után 1921 őszén nyílt meg az Orvosi Kar 14 elméleti intézete, valamint klinikája és indult el az orvosképzés. Az idők folyamán nemcsak az Egye- tem neve, hanem struktúrája is átalakult - Debreceni Magyar Királyi Tudományegyetem/Debreceni Tisza István Tudományegyetem. 1951ben megalakult az önálló Debreceni Orvostudományi Egyetem, amely ma a 2000-ben létrejött Debreceni Egyetem része, és amelynek Orvosés Egészségtudományi Centrum a neve. A Centrumot az Általános Orvostudományi, az Egészségügyi, a Fogorvos-tudományi, a Gyógyszerész-tudományi és a Népegészségügyi Kar alkotja.

- Ami Szeged egyetemi múltját illeti, 1921 nyarán a magyar kormány törvényben rögzítette a kolozsvári Magyar Királyi Ferenc József Tudományegyetemnek a városban való ideiglenes elhelyezését. A Kolozsvárról átmenekült Egyetem egyes részlegeit meglehetősen mostoha körülmények között, különböző épületekben helyezték el és így indult el/folytatódott az Orvosi Karon is az oktatás. Miután 1940-ben Erdélyt visszacsatolták, az Egyetem néhány oktatóval visszatelepült Kolozsvárra 
és ott folytatta a munkáját. Annak az évnek októberében Szegeden létrehozták a Magyar Királyi Horthy Miklós Tudományegyetemet, amely 1945-től Szegedi Tudományegyetem néven müködött. Ebből vált ki az Orvosi Kar 1951-ben és a továbbiakban, mint Szegedi Orvostudományi Egyetem oktatott, melynek a neve később Szent-Györgyi Albert Orvostudományi Egyetem lett. Jelenleg Szegedi Tudományegyetem Szent-Györgyi Albert Orvos-és Gyógyszerész-tudományi Centrum néven végzi munkáját. A Centrumot az Általános Orvostudományi Kar, a Fogorvos-tudományi Kar, az Egészségtudományi és Szociális Képzési Kar, valamint a Gyógyszerész-tudományi Kar alkotja.

- Az Országos Gyógyintézeti Központ története 1889-ben kezdődött, amikor a Pesti Izraelita Hitközség létrehozta a Szabolcs utcai Kórházát, melyet 1947-ben államosítottak, és mint Állami Kórház végezte a munkáját. 1956-ban az Intézmény neve Orvostovábbképző Intézet, majd 1985- ben Orvostovábbképző Egyetem, és 1993-tól Haynal Imre Orvostovábbképző Egyetem, végül 1998-tól Haynal Imre Egészségtudományi Egyetem lett, mely 2000-ben egyesült a Semmelweis Egyetemmel, mint annak egyik Kara. 2001 végén ez a Kar megszűnt, melynek egységei vagy a Semmelweis Egyetem részei lettek, vagy pedig az Országos Haematológiai és Immunológiai Intézettel egyesültek és közösen alkották az Országos Gyógyintézeti Központot, amely 2007-ben átalakult a Honvéd Kórház területén Állami Egészségügyi Központtá (ÁEK) a belügyi és a rendvédelmi szervek, a honvédség, valamint a MÁV kórházai és rehabilitációs intézetei integrációjával.

• Végül meg kell említenünk az egyetemi klinikákat, az egyes jelentős kórházainkat, az orvostudománnyal, valamint a közegészségüggyel foglalkozó kutató és vizsgáló országos intézményeinket, melyek szerves részét képezik az orvosi oktatásunk rendszerének. 
Csak mint érdekességet megemlítjük, hogy az 1918-ig a Magyar Királyság részét képező Horvátországban az első egyetem gyökerei 1669-ig nyúlnak viszsza, ugyanis ott akkor létesült az a kétkarú jezsuita Akadémia, amelyből kialakult az első egyetem Zágrábban. Ennek létesítését Ferenc József 1874. január 5-én szentesítette, és az Egyetem 1874. október 19-én nyílt meg két karral osztrák minta alapján. A zágrábi Ferencz József Egyetemnek később három kara lett. A negyedik az Orvosi Kar csak az 1917/1918-as tanévben alakult meg. Ebből következik, hogy Horvátországban és Szlavóniában is, 1925-ig Budapesten végzett orvosok is gyógyítottak.

\section{Meglbeszélés}

Összegezve az elmondottakat, megállapíthatjuk, hogy hazánkban állampolgárságát és képzettségét tekintve többféle orvos működhetett egykor és müködik ma is.
Kezdetben orvosi ismeretekkel rendelkező bencés egyházi személyek voltak a "szakképzett” gyógyítók. (Itt a táltosokkal, varázslókkal stb., nem foglalkozunk.) A papok tanulhattak külföldön vagy 1000 után itthon és lehettek magyarok vagy külföldiek. A másik csoportba tartoznak azok, akik 1180 előtt Salernoban, attól kezdve már Montpellierben is, ill. 1268-tól Bolognaban és végül 1292-től Párizsban, stb., szereztek orvosi ismereteket. Ök is lehettek külföldiek vagy egyre növekvő számban peregrináló magyarok. Az utóbbiak a bölcsészeti, jogi és/vagy teológiai alapismereteiket itthon a különböző Székesegyházi Iskolákban, a veszprémi Studium Generaleban, az Aquinói Szent Tamás nevű Studium Generaleban Budán, a pécsi Studium Generaleban vagy később a református, az evangélikus és a királyi kollégiumokban, lyceumokban, akadémiákon vagy főiskolákon szerezhették meg. Ha tovább akartak tanulni, és itthon akkor arra nem volt lehetőség, vagy a meglévő lehetőséggel nem akartak élni, abban az esetben az orvosi tudáshoz külföldön jutottak hozzá. Hogy hány szerzetes/pap/tiszteletes, ill. orvos 
gyógyított hazánkban, azt nem tudjuk. Erre vonatkozóan többek között Magyary-Kossa múvében, de mások közleményeiben is találunk adatokat. Bizonyos, hogy 1240 előtt diplomás orvos nálunk sem volt, továbbá, hogy itthon csak az 1279-es évi budai zsinat tiltotta meg a papoknak az égetéssel és vérzéssel járó sebészi mútétek végzését, tehát addig mindent csinálhattak. A kutatások eredményeiből az is megállapítható, hogy a különböző tisztségeket betöltő papjaink között hosszú időn keresztül sokan rendelkeztek orvosi ismeretekkel, ill., hogy a jól végzett gyógyító munkájuk elismeréseként gyakran kerültek ezek a személyek különböző magasabb papi pozícióba.

A peregrináció irányát és mértékét többen is tanulmányozták. A kutatások szerint a peregrinálők száma a XII. századtól III. Béla király törekvéseinek köszönhetően jelentősen emelkedett. A külföldi intézmény kiválasztását, a reformáció jelentkezése után elsősorban a tanulni vágyó vallási irányultsága - római katolikus, protestáns, stb. - határozta meg egyéb más szempontok - nyelv- tudás, szakmai érdeklődés, a személyes kapcsolatok és a távolság - mellett.

Hazánkban nevesített orvosképzés először 1389 és 1403 majd, 1410 és 1447 ? között az Universitas Budensissen Óbudán az első Orvosi Karon indult el. Ezt követően az Universitas/Academia Istropolitanán Pozsonyban 7465 és 1491 között, majd a nagyszombati/budapesti Orvosi Karon 1770-től folyt/folyik orvosok képzése. Ezeken kívül volt még egy rövid időszak 1769 és 1775? között, amikor Egerben a hivatalosan el nem ismert Érseki Főiskola/Egyetem Orvosi Karán is képeztek egészségügyi szakszemélyeket. Továbbá 1775 és 1784 között orvos-mester-képzés volt a Kolozsvári Egyetemen, majd az ottani Orvos-Sebészeti Tanintézetben is 1877 és 1872 között és 1872-től a harmadik Kolozsvári Egyetem Orvosi Karán. Ennek a Karnak a mai utóda a "George Emil Palade” Orvosi, Gyógyszerészeti, Tudomány és Technológiai - román és magyar nyelvú - Egyetem Marosvásárhelyen. Végül, de nem utolsó sorban, orvosi diplomához lehet jutni a pécsi, a debreceni és a szegedi egyetemeinken. 
Külön kategóriába tartozik az erdélyi Collegium Academicum/Egyetem (1622-1658), mely Gyulafehérváron létesült és ahol orvosok is oktattak, de azt nem tudjuk, hogy Orvosi Tanszéke volt-e és orvosi képesítést kaptak-e a végzősei?

Ugyancsak nehéz megállapítani a Mátyás király által állítólag megalapított ún. Budai Egyetemnek a létét és az orvosképzésben játszott esetleges szerepét.

Végül arról is szólnunk kell, hogy a középkorban a Felvidéken és Erdélyben voltak olyan neves orvosok, akik „házi oktatást" végeztek, megkönnyítendő a külföldön orvosi diplomát szerezni kívánó magyar fiatalok sikeres tanulását. Továbbá, hogy a pap/tiszteletes képzés során, praktikus megfontolásból hosszú ideig alap egészségügyi ismereteket is oktattak a különböző iskoláinkban.

\section{Felhasznált irodalom}

1. Banóné Fleischmann Marianna, Zalai Károly: A gyógyszerészi eskü kialakulása és fejlődése. Gyógyszerészet 22. 184-187, 1978.

2. Benke József. A Pécsi Orvostudományi Egyetem története. Pécs, 1992.

3. Benke József: Kis arcképcsarnok. Pécs, 2000.

4. Benke József: Az arab orvostudomány története a kalifátusok korában (632-1258). PTE ÁOK, Pécs, 2001.

5. Benke József: A pécsi orvosképzés intézetei és klinikái 1918-2008. Pécs, 2008.

6. Demkó Károly: A magyar orvosi rend története a XVIII. század végéig. Dobrovsky és Franke, Budapest, 1894.

7. Farkaslaki Hints Elek: Az orvostudomány fejlődése az emberiség müvelődésében.

8. Eggenberger-féle Könyvkereskedés, Rényi Károly kiadása, Budapest, 1939.

9. Farkaslaki Hints Elek: Az orvostudomány fejlődése az emberiség müvelödésében 2. (Különös tekintettel a magyar viszonyokra) négy kötetben, Eggenberger-féle Könyvkereskedés, Rényi Károly kiadása, Budapest, 1939. 
10. Haraszti Szabó Péter, Kelényi Borbála: Tanult orvosok a középkori Magyar Királyságban. Gerundium Egyetemtörténeti Közlemények III. (1-2), 39-78, 2016.

11. Kapronczay Károly: A bécsi egyetem orvosi karának és a Natio Hungaricának kapcsolatai (1381-1630). Orvostörténeti Közlemények 81. 27-41, 1977.

12. Kapronczay Károly: Fejezetek 125 év magyar egészségügyének történetéből.

13. Libri Historiae Medicae, Semmelweis Orvostörténeti Múzeum, Könyvtár és Levéltár, Budapest, 2001.

14. Kapronczay Károly: Adatok a magyar-örmény orvosok és gyógyszerészek történetéhez. Magyar-Örmény Könyvtár, $\underline{8}$. Holló és Társa Bt. Nyomdájában, Budaörs, 2002.

15. Kapronczay Károly (szerk.): Az orvostörténelem századai. Semmelweis Kiadó, Budapest, 2010.

16. Linzbauer Franciscus Xav:: Codex Sanitario-medicinalis Hungariae. Budae, Typis Regiae Scientiarum Universitatis Hungaricae, 1861.

17. Magyary-Kossa Gyula: Magyar orvosi emlékek. Budapest, Magyar Orvosi Könyvkiadó Társulat, 1931.

18. Ralovich Béla: Orvosi szavaink a kezdetektől 1600-ig. Orvosi Hetilap 155. 800-802, 2014.
19. Ralovich Béla: Formation of Knowledge of Causes of Infectious Diseases and Development of Specific Prevetion against them in Hungary from the Beginning till 1900. Acta Sci. Microbiol. 1. (4), 74-79, 2018.

20. Ralovich Béla: Adatok a mikrobiológiával kapcsolatos ismeretek oktatás- és kutatástörténetéhez. I., II., III., TSR Kft., Keszthely, 2011, 2014, 2018.

21. Ralovich Béla: A népünk eredetével és oktatásunk történetével kapcsolatos gomdolataink a Föld élete alakulásának fényében. Püski Kiadó, Budapest, 2019.

22. Schelenz Hermann: Geschichte der Pharmazie. G. Ohns - Verlag, Hildesheim, 1965.

23. Schultheisz Emil: A nagyszombati egyetem orvostanárai. Mesterek és tanítványok. Országos Pedagógiai Könyvtár és Múzeum, Budapest, 2004.

24. Schultheisz Emil: Medicina és organizáció. (A Magyar medicina a nagyszombati orvosi kar felállásáig) Valóság 니. (12), 1-7, 2008.

25. Simonyi Károly: A középkori egyetem. A hét szabad és a hét mechanikai múvészet. Ponticulus Hungaricus !. (1), 1997.

26. Szögi László (szerk.): Régi magyar egyetemek emlékezete. Válogatott dokumentumok a magyarországi felsőoktatás történetéhez. 1367-1777. Eötvös 
27. Loránd Tudományegyetem, Budapest, 1995.

28. Szögi László: Tanulmányok az Óbudai Egyetem történetéről 1395-1995. ELTE Eötvös Kiadó, Budapest, 1995.

29. Szögi László: Budai, pesti, óbudai és budapesti diákok egyetemjárása II. 1256-1525 és 1867-1919. Budapest Főváros Levéltára, Budapest, 2012.
30. Szerkesztett: Új magyar lexikon. I-VII. és a kiegészítő kötet, Akadémiai Kiadó, Budapest, 1960, 1962, 1972, 1981.

31. Szerkesztett: Orvosi Lexikon. Akadémiai Kiadó, Budapest, 1969.

32. Szerkesztett: Magyar Katolikus Lexikon. http://lexikon.katolikus.hu/ 